Jakub Hudský

Uniwersytet Wrocławski

DOI: $10.19195 / 1733-5779.22 .5$

\title{
Uwarunkowania prawne działalności gospodarczej w Czechach
}

JEL Classification: K200

Słowa kluczowe: działalność gospodarcza, Czechy, živnost

Keywords: business activity, the Czech Republic

\begin{abstract}
Abstrakt: W czeskim prawie gospodarczym funkcjonują równocześnie dwa pojęcia — działalność gospodarcza (hospodář́ská činnost) i živnost. Pomimo że definicje obu określeń są w merytorycznych elementach tożsame, živnost jest terminem węższym, zawierającym się w pojęciu działalności gospodarczej. Rodzaje działalności gospodarczej wchodzące w zakres živnosti prowadzone są na zasadach wskazanych w ustawie. Ustawowy zamknięty katalog negatywny pokazuje rodzaje działalności gospodarczej, niebędące živnostia, np. działalność lekarzy, adwokatów, tłumaczy przysięgłych lub rolników. W związku z tym można wskazać, że czeski ustawodawca przyjął podział działalności gospodarczej według kryterium przedmiotowego. Czeskie ustawodawstwo wyróżnia dwa typy działalności gospodarczej w ramach živnosti. Jest to działalność podlegająca zgłoszeniu (ohlašovací živnost) oraz działalność koncesjonowana (koncesovaná živnost). Przed osobami chcącymi prowadzić działalność gospodarczą w trybie živnosti, czeskie prawo ponadto stawia wymóg posiadania pełnej zdolności do czynności prawnych oraz wymóg niekaralności za przestępstwa umyślne popełnione w zakresie działalności gospodarczej lub jej przedmiotu.
\end{abstract}

\section{Legal aspects of business activity in the Czech Republic}

Abstract: There are two designations connected with business activity in Czech commercial legislation - business activity (hospodářská činnost) and živnost. Despite that the definitions of these terms are identical in substantive elements, the živnost is a narrower concept. The types of the živnost function in accordance to the rules indicated in the law. There are some types of business activities listed in the law, which are indicated as activity but not a živnost. For example, medical activity, activities of lawyers, activities of sworn translators, or agricultural activity. Czech legislation also distinguishes two main types of business activity in terms of živnost. Namely, notified business activity (ohlašovací živnost) and licensed activity. If an entity wishes to pursue a živnost business activity in the Czech Republic, there are two requirements: full legal capacity and no criminal records on business.

Studenckie Prace Prawnicze, Administratywistyczne i Ekonomiczne 22 


\section{Wprowadzenie}

Prawo Republiki Czeskiej, szczególnie w zakresie regulacji dotyczących działalności gospodarczej i spraw handlowych, w ostatnim czasie stanowi przedmiot zainteresowania polskiej doktryny. Zaciekawienie sposobami i warunkami prowadzenia przedsiębiorstwa zgodnie z zasadami prawa czeskiego wynika przede wszystkim — jeżeli wierzyć doniesieniom medialnym — ze wzrostu aktywności polskich podmiotów gospodarczych na czeskim rynku oraz z coraz popularniejszego przenoszenia działalności gospodarczej za południową granicę.

Prowadzenie działalności gospodarczej w Czechach zostało uregulowane w trzech podstawowych aktach prawnych. Są to: Zákon o živnostenském podnikáni (živnostenský zákon) ${ }^{1}$, Zákon o obchodních korporacích ${ }^{2}$ oraz Občanský zákoník ${ }^{3}$.

Občanský zákoník - nowy czeski kodeks cywilny z 2012 roku — zakreśla ogólne ramy prawne przedsiębiorczości i obrotu gospodarczego; w porównaniu z polską regulacją jest to akt o wiele bardziej kompleksowy, zawierający nie tylko normy prawa cywilnego sensu stricto, lecz także przepisy z zakresu chociażby prawa rodzinnego czy handlowego. $Z$ kolei Zákon o obchodních korporacích w największej mierze reguluje formy organizacyjne prowadzenia działalności gospodarczej przez osoby prawne. Trzeci z wskazanych aktów prawnych Živnostenský zákon — stanowi szczegółowe unormowanie, które charakteryzuje sposób i formę prowadzenia określonej działalności gospodarczej.

Podstawowym problemem, z jakim spotykamy się podczas analizy przepisów czeskiego prawa gospodarczego, jest równoczesne funkcjonowanie dwóch określeń - działalność gospodarcza (hospodářská činnost) i živnost. Należy podkreślić, że wbrew znacznym podobieństwom są to dwa odrębne pojęcia, a ich rozróżnienie jest niezwykle istotne dla zrozumienia czeskiego prawa handlowego.

Działalność gospodarcza obecnie nie posiada w Czechach legalnej definicji. Została ona jednak zawarta w nieobowiązującym już od 2013 roku czeskim kodeksie handlowym (Obchodní zákoník ${ }^{4}$ ). Wskazany akt prawny w $§ 2$ ust. (1) stanowił, że działalność gospodarcza to systematyczna działalność prowadzona przez przedsiębiorcę samodzielnie, we własnym imieniu i na własną odpowiedzialność w celu osiągnięcia zysku. Z kolei pojęcie živnost zostało zdefiniowane w $§ 2$ ustawy živnostenský zákon. Zgodnie z nim jest to działalność systematyczna, prowadzona samodzielnie, we własnym imieniu, na własną odpowiedzialność, w celu osiągnięcia zysku i na zasadach ustanowionych ustawą živnostenský zákon.

1 Zákon č. 455/1991 Sb. z dnia 2 października 1991 r. o živnostenském podnikání (živnostenský zákon), tłum. ustawa o działalności gospodarczej.

2 Zákon č. 90/2012 Sb. z dnia 25 stycznia 2012 r. o obchodních korporacích a družstvech (zákon o obchodních korporacích), tłum. ustawa o korporacjach handlowych i spółdzielniach.

3 Zákon č. 89/2012 Sb. z dnia 3 lutego 2012 r. občanský zákoník, tłum. kodeks cywilny.

4 Zákon č. 513/1991 z dnia 5 listopada 1991 r. obchodní zákoník, tłum. kodeks handlowy. 
Należy zauważyć, że obie definicje są pod względem merytorycznym tożsame. Jednakże pojęcie živnosti jest węższe, bowiem živnost to taki rodzaj działalności, którą prowadzi się na zasadach określonych w ustawie živnostenský zákon ${ }^{5}$. Wszystkie inne typy działalności gospodarczej, niebędące živnostią, zostały wskazane w negatywnym katalogu taksatywnym $\S 3$ ustawy. W przepisie zostały wyliczone rodzaje działalności, które spełniają przesłanki właściwe dla živno$s t i$, lecz z różnych powodów zostały wyłączone z zakresu ustawy i co do zasady są uregulowane w odrębnych ustawach. Spod zakresu przedmiotowego ustawy živnostenský zákon wyłączona została np. działalność związana z udzielaniem usług medycznych, działalność adwokatów, notariuszy, rzeczników patentowych, komorników, tłumaczy przysięgłych i biegłych. Jako živnost nie kwalifikuje się także działalność z zakresu górnictwa (wydobywania kopalin) i z zakresu energetyki. Odrębnie uregulowano również działalność rolniczą.

W związku z tym można by pokusić się o stwierdzenie, że w czeskim prawie podział działalności gospodarczej nie odbywa się w pierwszej kolejności według kryterium formy, lecz według kryterium jej przedmiotu (czy jest to živnost, czy działalność ,szczególna”, uregulowana odrębną ustawą). Podział ten ma konsekwencje chociażby w zakresie rejestrów gospodarczych. W Czechach funkcjonuje rejestr osób prowadzących živnost (živnostenský rejstř́k), który jest administrowany przez Urząd Živnosti Republiki Czeskiej (Živnostenský úřad České republiky). Obowiązkowi wpisu do tego rejestru podlegają osoby fizyczne i prawne prowadzące działalność gospodarczą w trybie živnosti. Drugim istotnym rejestrem publicznym istniejącym w czeskim prawie jest rejestr handlowy (obchodni rejstřik). Jest on prowadzony przez sądy rejestrowe i obowiązkowi wpisu do niego podlegają nie tylko spółki handlowe i spółdzielnie, lecz także niektóre osoby fizyczne. Do rejestru handlowego wpisuje się te osoby fiyczne, które prowadzą działalność gospodarczą, mają miejsce zamieszkania na terenie Republiki Czeskiej i wniosły o dokonanie wpisu. Wpis do rejestru jest obowiązkowy dla osób fizycznych, których średni dochód, obniżony o wartość podatku VAT, za dwa ostatnie okresy sprawozdawcze przekroczył wysokość 120 milionów czeskich koron.

Z powyższego wynika, że czeski ustawodawca zrezygnował z podziału rejestrów handlowych według kryterium rodzaju osoby (fizycznej czy prawnej), ale skupił się — jak już była mowa wcześniej — na kryterium przedmiotowym i innych okolicznościach.

Aby opisać wszystkie najistotniejsze pojęcia związane z działalnością handlową w Czechach, należy na koniec wskazać ogólną definicję legalną przedsiębiorcy, zawartą w $§ 420$ kodeksu Občanský zákoník. Stanowi ona, że kto samodzielnie, na własny rachunek i odpowiedzialność wykonuje działalność w trybie działalności gospodarczej, lub w inny analogiczny sposób, z zamiarem działania w ten sposób

5 P. Kameník, M. Hrabánková, M. Orlová, Živnostenský zákon. Zákon o živnostenských úřadech. Komentár̆, Praha 2014, komentarz do 2 . 
systematycznie w celu osiągnięcia zysku, jest uważany, z uwagą na tę działalność, za przedsiębiorcę. Warto zauważyć, że przedstawiony przepis ustanawia jednolite pojęcie przedsiębiorcy, obejmujące zarówno osoby fizyczne, jak i prawne ${ }^{6}$. Ponadto należy również podkreślić, że powyższa regulacja nie charakteryzuje oddzielnie pojęcia przedsiębiorcy i pojęcia działalności gospodarczej. Ustawa bowiem wskazuje, że przedsiębiorcą jest każdy, kto wykonuje działalność w trybie živnosti lub w inny sposób, mając na celu rynkowy sukces w konkurencji z innymi i uzyskanie dla siebie korzyści gospodarczej?

\section{Podmioty prowadzące działalność gospodarczą}

Mając na uwadze fakt, że živnost jest najpopularniejszym rodzajem działalności gospodarczej, dotyczącym przeważającej części podmiotów, w dalszej części artykułu skupię się właśnie na zasadach, warunkach i prawnych okolicznościach jej wykonywania. Ustawa w $\S 5$ wskazuje podmioty, które po spełnieniu określonych warunków mogą prowadzić živnost na terenie Republiki Czeskiej. Osoby, które uzyskają uprawnienia do prowadzenia działalności gospodarczej, ustawa nazywa przedsiębiorcami. Należy jednak odróżnić pojęcie przedsiębiorcy w rozumieniu tej ustawy (węższe znaczenie) od przytoczonego wyżej pojęcia przedsiębiorcy w rozumieniu czeskiego kodeksu cywilnego (szersze znaczenie).

Przedsiębiorca w rozumieniu ustawy živnostenský zákon może być zarówno osobą fizyczną, jak i osobą prawną. Może to być także osoba krajowa, tj. posiadająca miejsce zamieszkania lub siedzibę w Czechach, albo osoba zagraniczna ${ }^{8}$. Osoby zagraniczne — w rozumieniu ustawy — dzielą się na osoby z państw Unii Europejskiej i osoby poza unijne.

Živnostenský zákon w $§ 6$ ust. (1) stanowi ogólne warunki, które musi spełnić osoba fizyczna chcąca uzyskać uprawnienia do prowadzenia działalności gospodarczej w trybie živnosti. Po pierwsze, musi ona posiadać pełną zdolność do czynności prawnych. W niektórych wypadkach zdolność taka może być zastąpiona przychyleniem się sądu do zgody przedstawiciela ustawowego osoby niepełnoletniej na prowadzenie działalności gospodarczej ${ }^{9}$. Drugim wymogiem stawianym przed osobą fizyczną w związku z prowadzeniem działalności gospodarczej jest niekaralność. Ustawa w ust. (2) wskazanego przepisu stanowi, że na potrzeby ustawy za osobę niekaralną nie uznaje się osoby, która była prawomocnie skazana za przestępstwo umyślnie popełnione w związku z działalnością gospodarczą lub jej przedmiotem.

\footnotetext{
6 J. Bejček et al., Obchodní právo. Obecná část. Soutěžní právo, s. 55.

7 Ibidem.

8 P. Kameník, M. Hrabánková, M. Orlová, op. cit., komentarz do $§ 5$.

9 J. Bejček et al., op. cit., s. 64.
} 


\section{Rodzaje działalności gospodarczej}

$\mathrm{Na}$ gruncie regulacji ustawy živnostenský zákon podstawowym rodzajem živnosti jest živnost podlegająca zgłoszeniu (ohlašovaci živnost ${ }^{10}$ ). Aby wykonywać taki rodzaj działalności, należy spełnić ewentualne ustawowe przesłanki i zgłosić živnost we właściwym urzędzie (Živnostenský úřad). W takich wypadkach dniem rozpoczęcia prowadzenia działalności gospodarczej jest co do zasady dzień zgłoszenia działalności.

Czeskie prawo wyróżnia trzy rodzaje ohlašovací živnosti. Jest to živnost rzemieślnicza (řemeslná živnost), živnost regulowana (živnost vázaná) oraz živnost wolna (živnost volná) ${ }^{11}$.

Živnost rzemieślnicza została wyodrębniona ze względu na fakt, że do jej wykonywania potrzebne są fachowe kwalifikacje. Dokumenty, jakimi można wykazać posiadanie takowych, określone zostały w $§ 21$ i $§ 22$ ustawy živnostenský zákon. Zaliczają się do nich np. dokument potwierdzający ukończenie szkoły średniej (świadectwo ukończenia szkoły zawodowej) lub dokument potwierdzający ukończenie szkoły wyższej. Ustawa w $§ 7$ ust. (5) wskazuje również, że w zależności od typu živnosti rzemieślniczej fachowe kwalifikacje można wykazać poprzez określoną liczbę lat przepracowanych w dziedzinie danego rzemiosła.

W załączniku nr 1 do ustawy živnostenský zákon zostały taksatywnie wymienione wszystkie rodzaje živnosti rzemieślniczej, i są to np. działalność piekarza, cukiernika, rzeźnika, piwowara, kowala, zegarmistrza, jubilera, murarza, malarza, zduna czy hydraulika.

Živnost regulowana, opisana w $\S 23$ i $§ 24$ ustawy, jest w swoich podstawowych elementach w znacznym stopniu podobna do živnosti rzemieślniczej. Aby ją prowadzić, również należy posiadać fachowe kwalifikacje. Różnica polega jednak na tym, że nie są to już ogólne kategorie kwalifikacji, jak w wypadku rzemiosła, lecz konkretne kwalifikacje potrzebne do wykonywania określonej živnosti. W załączniku nr 2 do ustawy živnostenský zákon zamieszczono katalog działalności i kwalifikacje potrzebne do ich wykonywania. Aby móc np. prowadzić szkołę prawa jazdy, należy posiadać zawodowe zaświadczenie wydane we właściwym urzędzie wojewódzkim (krajský úr̆ad) oraz rok praktyki w danej dziedzinie.

Trzecim rodzajem živnosti podlegającej zgłoszeniu jest živnost wolna. Jak sama nazwa wskazuje - do jej prowadzenia nie są wymagane żadne fachowe kwalifikacje. Przyjmuje się, że jest to każda živnost niebędąca živnostią rzemieślniczą, regulowaną ani koncesjonowaną.

$10 \mathrm{~W}$ polskich tłumaczeniach rodzajów działalności gospodarczej w Czechach można znaleźć daleko idące rozbieżności.

11 S. Černá et al., Obchodní právo — podnikatel, podnikání, závazky s účastí podnikatele, Praha 2016, s. 132. 
Obok živnosti podlegającej zgłoszeniu czeskie prawo wyróżnia także — wyżej wspomnianą — živnost koncesjonowaną ${ }^{12}$. Warunkiem prowadzenia tego rodzaju działalności gospodarczej jest uzyskanie decyzji administracyjnej o udzieleniu koncesji ${ }^{13}$. Typy działalności koncesjonowanej zostały wyliczone w załączniku nr 3 do ustawy živnostenský zákon, i są to np. badanie, rozwój, niszczenie, unieszkodliwianie, przetwarzanie, kupno, sprzedaż i wykonywanie prac z materiałami wybuchowymi; produkcja i przetwarzanie paliw; śródlądowy transport wodny; przeprowadzanie aukcji publicznych; prowadzenie biura podróży; ochrona majątku i osób; usługi detektywów prywatnych; prowadzenie zakładu pogrzebowego; prowadzenie krematorium.

\section{Wybrane obowiązki przedsiębiorcy}

Obowiązki przedsiębiorcy prowadzącego działalność w trybie živnosti reguluje $\S 31$ ustawy. Stosownie do ust. (2) wskazanego paragrafu przedsiębiorca ma obowiązek w widoczny sposób określić firmą handlową (ewentualnie nazwą, imieniem i nazwiskiem lub numerem identyfikacyjnym IČO osoby, jeżeli został nadany) obiekt, w którym znajduje się jego siedziba. Ustawa zwalnia przedsiębiorcę z takiego obowiązku w wypadku, gdy adres siedziby jest tożsamy z jego miejscem zamieszkania. Na podstawie wskazanego przepisu przedsiębiorca jest także zobowiązany — na żądanie właściwego urzędu (Živnostenský úřad) — wykazać podstawę prawną korzystania z pomieszczeń, w których mieści się jego siedziba. Ustawa zwalnia przedsiębiorcę także z tego obowiązku, jeżeli jego miejsce zamieszkania jest tożsame z siedzibą.

Ustęp (3) stanowi o obowiązku przedsiębiorcy do wykazania na żądanie organu kontroli w ustanowionym terminie sposobu nabycia sprzedawanego towaru lub materiału wykorzystywanego do wykonywania usług. Inny istotny obowiązek przedsiębiorcy wynika z ust. (8) przepisu, który stanowi, że przedsiębiorca ma obowiązek zapewnić - w miejscu wykonywania działalności, przeznaczonym do sprzedaży towaru lub świadczenia usług, w czasie przeznaczonym do kontaktu z konsumentem - obecność osoby spełniającej warunek znajomości języka czeskiego albo słowackiego. Jeżeli Živnoskenský úřad będzie miał w tym zakresie wątpliwości, może badać spełnienie warunku rozmową, podczas której ocenia, czy wskazana osoba jest zdolna płynnie i poprawnie reagować na pytania dotyczące zwykłych sytuacji życia codziennego i przedsiębiorczości. Urząd może również sprawdzić, czy taka osoba potrafi ustnie komunikować treść tekstu z prasy codziennej.

Przedsiębiorca na gruncie $\S 31$ ust. (9) ponosi odpowiedzialność za wykazanie przez swoich pracowników spełnienia warunku niekaralności, jeżeli ustawa

\footnotetext{
12 J. Bejček et al., op. cit., Praha 2014, s. 63.

13 Ibidem.
} 
lub przepis szczególny wymagają spełnienia takiego warunku. Z ust. (15) wynika kolejny obowiązek przedsiębiorcy: jest on zobowiązany na żądanie urzędu przekazać informację, czy wykonuje živnost i przedstawić dokumenty potwierdzające jej wykonywanie.

\section{Podsumowanie}

Jak widać, czeskie regulacje prawne dotyczące prowadzenia działalności handlowej - wbrew temu, co mogłoby się wydawać — różnią się od polskich unormowań. Najbardziej zaskakujący wydaje się sposób, w jaki czeski ustawodawca uregulował zagadnienie działalności gospodarczej. Podział działalności gospodarczej na živnost i działalność wykonywaną w trybie odrębnej ustawy jest diametralnie różny od polskiej klasyfikacji przedsiębiorców. Na pierwszy rzut oka polskiego prawnika mogłoby się wydawać, że takie rozwiązanie przysparza w codziennym obrocie gospodarczym sporych problemów i komplikacji. System podziału działalności handlowej przyjęty w Czechach funkcjonuje jednak bardzo dobrze i sprawnie.

Różnice między czeskimi a polskimi rozwiązaniami prawnymi mogą być bardziej zadziwiające, jeżeli weźmiemy pod uwagę, że geneza obu systemów prawnych jest w znacznym stopniu zbliżona. Zarówno prawo czeskie, jak i polskie wywodzą się przecież z szeroko pojętego prawa niemieckiego (czeskie konkretnie $\mathrm{z}$ austriackiego). Systemy prawne obu krajów musiały uporać się także ze znaczną degradacją prawa handlowego podczas ponad 40-letniego okresu panowania ustroju socjalistycznego.

\section{Bibliografia}

Bejček J. et al., Obchodní právo. Obecná část. Soutěžní právo, Praha 2014.

Černá S. et al., Obchodní právo — podnikatel, podnikání, závazky s účastí podnikatele, Praha 2016. Kameník P., Hrabánková M., Orlová M., Živnostenský zákon. Zákon o živnostenských úřadech. Komentár. ., Praha 2014.

Rozehnal A. et al., Obchodní právo, Pilzno 2014.

\section{Akty prawne}

Zákon č. 455/1991 Sb. z dnia 2 października 1991 r. o živnostenském podnikání.

Zákon č. 90/2012 Sb. z dnia 25 stycznia 2012 r. o obchodních korporacích a družstvech.

Zákon č. 89/2012 Sb. z dnia 3 lutego 2012 r. občanský zákoník.

Zákon č. 513/1991 Sb. z dnia 5 listopada 1991 r. obchodní zákoník. 


\section{Legal aspects of business activity in Czech Republic}

Summary

Czech law distinguishes two designations connected with business activity — business activity (hospodářská činnost) and živnost. Both terms have identical substantial elements in their definitions but živnost is obviously narrower concept. It means that there are some types of business activities, which are indicated as different activity than živnost (e. g. medical activity, activities of lawyers, activities of sworn translators etc.). There are two main types of živnost - notified business activity and licensed activity. 